\title{
INVESTIGATING 'WHATSAPP' FOR COLLABORATIVE LEARNING AMONG UNDERGRADUATES
}

\author{
Silas UDENZE*, Barth OSHIONEBO**
}

Received: 12.12.2019 - Accepted: 04.03.2020

Udenze, S. and Oshionebo, B. (2020). "Investigating 'Whatsapp' for Collaborative Learning among Undergraduates". Etkileşim. 5. 24-50.

\begin{abstract}
The adoption of new media technologies is rapidly becoming a trend in educational environment. Given the growing popularity of social media, it has become pertinent to understand and adopt social media networks in developing future educational blue prints. This study investigates the extent to which WhatsApp platform could engender collaborative learning among undergraduate students in the University of Abuja, Gwagwalada, Nigeria. To achieve this aim, a dual research methodology was employed to drive the study. Both survey and Focus Group Discussion (FGD) were employed respectively. Surveying 400 undergraduates, data from the survey were analysed using Simple Percentage Table (SPT) and Microsoft Office tools, while data that emanated from the focus group were analysed thematically. The study incorporated 'Technology Acceptance Model' (TAM) to direct and guide it. Discoveries from the study found that "perceived usefulness" and "perceived ease of use" engender the use of WhatsApp among students. Also, it was discovered that students incorporated and domesticated class WhatsApp group for various purposes, particularly for learning. Overall, the study found that class WhatsApp group engenders collaborative learning to a large extent. However, it was discovered that the major challenge in class WhatsApp groups is the posting of irrelevant contents on the platforms. The study concluded that it is paramount to fully harness the potentials of WhatsApp in order to enhance learning in higher institutions.
\end{abstract}

Keywords: social media, WhatsApp, undergraduate, collaborative learning, new media.

* Postgraduate Candidate, Department of Media Arts, University of Abuja, udenzes@gmail.com, Orcid: 0000-0002-4785-2126

** Professor, Faculty of Arts, University of Abuja, barthoshionebo@gmail.com 


\title{
LISANS ÖC̆RENCILERI VE işBIRLIKLI ÖĞRENME: 'WHATSAPP' ÖRNEĞi
}

\author{
Silas UDENZE*, Barth OSHIONEBO**
}

Gönderim Tarihi: 12.12.2019 - Kabul Tarihi: 04.03.2020

Udenze, S. and Oshionebo, B. (2020). “Investigating 'Whatsapp' for Collaborative Learning among Undergraduates". Etkileşim. 5. 24-50.

\section{Özet}

Yeni medya teknolojilerinin benimsenmesi eğitimde hızla bir eğilim haline gelmektedir. Sosyal medyanın artan popülaritesi göz önüne alındığında, gelecekteki eğitim projelerinin geliştirilmesinde sosyal medya ağlarını anlamak ve benimsemek geçerli hale gelmiştir. Bu çalışma, WhatsApp platformunun Nijerya, Gwagwalada'daki Abuja Üniversitesi'ndeki lisans öğrencileri arasında işbirlikli öğrenmeyi nasıl sağlayabileceğini araştırmaktadır. Bu amaçla, çalışmayı yürütmek için ikili bir araştırma metodolojisine başvurulmuş, anket ve odak grup görüşme yöntemi (FGD) kullanılmıştır. Toplamda 400 lisans öğrencisine anket uygulanmış, anketten elde edilen veriler basit yüzde tablosu ve Microsoft Office araçları kullanılarak analiz edilmiş ve odak grup görüşmesinden çıkan veriler tematik olarak analiz edilmiştir. Çalışma bu amaçla 'Teknoloji Kabul Model'ini (TKM) içermektedir. Araştırmadan elde edilen sonuçlar, "algılanan fayda" ve "algılanan kullanım kolaylığı"nın öğrenciler arasında WhatsApp kullanımına yol açtığını ortaya koymuştur. Ayrıca, öğrencilerin sınıf WhatsApp grubunu çeşitli amaçlar için, özellikle öğrenme için kullandıkları saptanmıştır. Çalışmada sınıf WhatsApp gruplarının işbirlikli öğrenmeye büyük ölçüde katkı sağladığı sonucuna ulaşılmıştır. Bununla birlikte, sınıf WhatsApp gruplarındaki en büyük zorluğun, platformlarda alakasız içeriklerin paylaşılması olduğu saptanmıştır. Çalışmada yüksek kurumlarda öğrenmeyi artırmak için WhatsApp'ın potansiyellerinden tam olarak yararlanmanın elzem olduğu sonucuna varılmıştır.

Anahtar Kelimeler: sosyal medya, WhatsApp, lisans, işbirlikli öğrenme, yeni medya.

* Doktora Adayı, Medya Sanatları Bölümü, Abuja Üniversitesi, udenzes@gmail.com, Orcid: 0000-0002-4785-2126 ** Profesör, Sanat Fakültesi, Abuja Üniversitesi, barthoshionebo@gmail.com

ISSN: 2636-7955 | Yıl 3 |Sayı 5 Nisan 2020 | ETKíleşiM | 25 


\section{Introduction}

Technology can become the wheel that will spur the educational world to fly farther and faster than ever before if we will allow it (Ansary and Behera 2018: 1). Information and Communication Technology (ICT) has continued to exact huge influences on various aspects of our lives. Notably, continuous innovation in mobile phone technology has helped in improving communication. With the increasing use of mobile technology like tablets, pads, iPhones, personal computers among youths, especially those in institutions of higher learning, in addition to the availability of internet services and cheap data, students have not only adopted this technology for communication; it has been extended to learning. According to Downes (2008), technology will continue to impact on learning. This statement can be linked to the phenomenon of online learning. Ling (2016) corroborates this by submitting that online learning is an additional/alternative platform for learners to share ideas, thoughts or even resources. Learning online or mobile learning is learning using wireless technology-mediated devices that are used wherever the user can access uninterrupted network connection (Attewell and Savill-Smith, 2005 as cited in El-Hussein and Cronje, 2010). In a clearer statement, Nyiri (2002) argues that online learning eliminates the instrumentalities of traditional learning environment like a classroom, lecture halls, and laboratories. Sharple (2007), as cited in Fuad, Madar and Marwan (2013) elaborate that the innovation in technology has provided us with the opportunity to choose a learning method that enables us to create a community of learners and interact with them in real-time in a virtual world.

This study investigates the popular social networking site (SNS), WhatsApp, specifically, the group chat features of this instant messaging application and its potential to engender collaborative learning. Students of tertiary institutions are tech-savvy, and WhatsApp is adjudged to be one of the most preferred social media for students when it pertains to communication.

As of January 2017, WhatsApp was rated as most popular messaging application in the world (statista.com). In April 2013, it recorded 200 million active users, but recently, in April 2016 it rose to 1 billion active users. WhatsApp was invented in 2009 by two former Yahoo! Staff; Jan Koun and Brian Acton (Amry, 2014; Ling, 2016; Mistar and Embi, 2016; Mefolere, 2016). The mobile application works across different operating devices like, iOS, Android, Windows, and Java (Alsaleem, 2016). This implies that WhatsApp can be installed and used on iPhones, iPad, Android devices, Java phones, Microsoft Windows Phones, and even on the desktop. Initially, WhatsApp 2.0 was released exclusively for Apple iPhone (Ling, 2016). Furthermore, Ling (2016) asserts that subsequently, the feature of sending pictures was incorporated into WhatsApp and its user grew rapidly and it became top among the 20 Apps in the US. The messaging device was officially released into the market in 2010 and its first operating device was Blackberry (Ling, 2016). WhatsApp can perform diverse functions like sending of text messages, picture and video transfers, voice call, location

\section{6 | ETKíleşim | Yıl 3 |Sayı 5 |Nisan 2020}


tracking, links to web addresses (Bounik and Deshen, 2014; Alsaleem, 2016). The company's headquarters is located in Mount View, California in the United States. In 2014, Facebook acquired WhatsApp for \$19 billion (WhatsApp, 2016).

Patil, Deepthi and Tadasad cited in Mefolere, (2016) state that WhatsApp is an instant messaging free application that is beneficial. The Application is downloadable, and the installation is fast and easy (Ling, 2016). To use WhatsApp, one needs to have an internet connection. Also, the receiver of the message at the other end must have the application installed on the phone. Conversion on WhatsApp can be on a one-to-one basis or in a group (Ling, 2016). The latter allows up to 250 persons at a time. According to Bounik and Deshen (2014), the group chat is a unique feature of WhatsApp, and it permits communication within defined boundaries. The initiator of the group becomes the administrator, he or she is privileged to add or remove members. He/she also performs the function of changing the profile picture of the group. Members of the group have equal rights. Participants receive any message that is sent to the group, and they can respond equally. WhatsApp (2010) cited in Amry (2014), postulates that the application has the following collaborative characteristics:

1. It enables the creating of groups between students or instructors.

2. The platform provides the ability for students to send messages without limitation.

3. It provides students with the ability to exchange text messages, images, videos, and voice notes to their social network or group and contacts.

4. Students use WhatsApp through a variety of mobile devices, such as Smartphone, tablets, iPad etc.

There is an increase in the demand for smartphones among youths. It is obvious that these increased yearnings for smartphones may have a huge impact on the use of WhatsApp. Studies (Church and Oliviera, 2013; Yeboah and Ewur, 2014; Alsaleem, 2016; Ling, 2016; Mefolere, 2016) have submitted that WhatsApp is widely used because of its ease of use and accessibility features.

\section{Statement of the Problem}

Technology may continue to impact our lives in different ways. Improvement in technology is gradually changing learning environments. Recently, learning is going beyond the known traditional learning environment- the four walls of the classroom, to the virtual learning environment that transcends time and boundaries. Studies have investigated the use of instant messengers (IMs) for learning, but the understanding of how WhatsApp can effectively be adopted for learning remains a domain worth examining. As stated earlier, the num- 
ber of undergraduates who own smartphones is rapidly increasing on a daily basis, and invariably, this increase in phone ownership may imply an increase in the use of WhatsApp. Online communication between groups of students and between students and instructors has become common during the last decades via different media like Email, SMS, Facebook groups, Twitter, and recently WhatsApp (Bounik and Deshen, 2014). However, in Nigeria, the number WhatsApp users are on the increase but its adoption for learning has not has investigated to the best of my knowledge. WhatsApp is popular among students largely because of its capability to hold group chats, voice messages, emoticons, phone call and even location sharing (Ling, 2016). Other features that have endeared youth to WhatsApp are its affordability and ease of use. Plethora of studies have been done on the use of WhatsApp for teaching languages in higher institutions including its impact on students' behaviour and achievement in the respective concerns (Riyanto, 2013; Bounik and Deshen, 2014; Yeboah and Ewur, 2014; Alsaleem, 2014; Plana et al, 2014; Chuah, 2014; Amry 2014; Chu and Toh, 2014; Mistar and Embi, 2016; Kopung, 2016; Minhas, Ahmed and Ullah, 2016). However, fewer researches have been carried out on the use of WhatsApp for collaborative learning among undergraduates. It is also germane to state that, generally, WhatsApp is grossly under-investigated in Nigeria.

With the increase in the number of undergraduates who own smartphones and other internet-enabled devices like tablets and iPads in our universities today, and the affordability, and easy use of WhatsApp, chat groups are created within and beyond the classrooms. The usual purpose behind the creation of groups is to provide a platform for students to connect with a group and share information and resources either for social or academic gains. Hence, the study explores the use of WhatsApp group for collaborative learning among undergraduates and also examines their use of the group as a communication platform.

\section{Objectives of the Study}

The main aim of this WhatsApp research is to explore the extent to which WhatsApp platform can be domesticated as a collaborative learning platform by undergraduate students.

Other objectives are:

1. To find out if undergraduates are on their class WhatsApp platform.

2. To explore why undergraduates use WhatsApp.

3. To examine undergraduates use WhatsApp platform for collaborative learning.

4. To research undergraduates' use of WhatsApp as a communication platform compared to phone calls and SMS.

28 etKileşim | Yıl 3|Sayı 5 | Nisan 2020 
5. To investigate the challenges undergraduates encounter while using WhatsApp group for collaborative learning/communication.

\section{Research Questions}

To address the research objectives, these research questions were posed to guide the study:

1. Are undergraduates in their class WhatsApp platform?

2. What are undergraduates' reasons for using WhatsApp?

3. To what extent do undergraduates use WhatsApp platform for collaborative learning?

4. Do undergraduates use WhatsApp for communication purpose compared to phone calls and SMS?

5. What challenges/problems do undergraduate encounter while using WhatsApp platform for collaborative learning and communication?

\section{Review of Related Literature}

\section{The New Media: Social networking sites (SNS)}

The common thing among young people these days is social media. Youth have continuously used social media every time of the day. According to Sajithra and Patil (2013), one major component of social media is social networking sites. Besides, social networking sites have continued to attract the attention of academics and industry scholars because of its affordance and reach (Boyd and Ellison, n.d). In 2007, the early pioneers of social media scholarship, Danah Boyd and Nicole Ellison (2013) explained social networking sites as web-based platforms that permit individuals to initiate a public or semi-public profiles within a confined system. Individuals also articulate a list of other individuals whom they share a common connection, and view the profiles of friends and those made by other individuals within the system. Furthermore, (Boyd and Ellison, n.d) identified the first recognizable social network site launched in 1997 was SixDegrees.com and it began operation in 1998.

Social networking sites (SNS) have become well-known in today's e-community as they provide a platform for people over the globe to communicate, exchange ideas, share knowledge, interests and send messages to each other regardless of geographic distance (Sawyer, 2011). Individuals engage in online discussion without being face-to-face with other participants (Yin, 2016). Sawyer (2011) went further to argue that social network sites have advanced the exchange of messages between individuals around the world so that they can use the Internet to interact and collaborate with others. WhatsApp possesses these intriguing features of breaking geographic barriers; it also facili- 
tates collaboration due to its group chat features.

\section{'WhatsApp' platform}

WhatsApp is a multimedia communication platform that allows users to send contents like pictures, audio, videos, make voice calls, send document etc. The unique feature of the mobile application has made one of the best in the world. Another unique feature of WhatsApp is its group chat feature. The group chat feature allows you to communicate with up to 256 people at once (whatsapp.com, 2017). The group chat platform on WhatsApp affords a diverse form of online community to emerge; individuals that share similar interests from different backgrounds like the academic, religious, entertainment, management, media, professional body etc. have come to see the importance of the WhatsApp group. Besides the maximum number (256) of people you can add to a group, there is something to keep in mind about WhatsApp group chat:

1. You may create as many numbers of groups.

2. Every group has one or more administrator (Group Manager). Only the administrator can add or remove participants.

3. Only an administrator can make other participants administrator.

4. If the last admin leaves the group, a new admin will be randomly assigned.

5. You can always control your participation in a group by staying in or leaving the group when you wish. Remember that only group administrators can add participants. If you have any question about being added to a group or prefer not to be added, please speak to a group administrator.

6. If you have blocked a contact, you will still receive messages this contact sends to any group you have in common. Likewise, they will still receive messages you send to those groups (whatsapp.com, 2017).

\section{Building shared interest: Online community}

Etienne Wenger in UNICEF (n.d) asserted online community brings together people who share a common interest for something they do and learn the ways to do it better as they interact regularly. Also, Helen Baxter (n.d) defines online community as a virtual community that is a conglomerate of individuals who may or may not meet one another face to face, and who transmit ideas through the mediation of computer. Pointing from the theory of connectivism, the use of an application like WhatsApp engenders a sense of online community (Rovai, 2002). Westheimer and Kahne (as cited in Rovai, 2002) state that an online community is a product of interaction and consideration by people with the same goals and interests.

30 | ETKíleşim | Yıl 3 |Sayı 5 | Nisan 2020 
Ling (2016) believes that the main reason behind the creating of groups is to communicate and share information deemed to be of interest and meaningfulness to the members of the group. WhatsApp as an online community helps students to contact each other after lecture hours (Yin, 2016). The information shared comes in a multiplicity of multimedia forms, which corroborate the appeal of WhatsApp (Ling, 2016). The activeness of the online group depends chiefly on the members' vibrancy in communicating and the group administrator in initiating interaction. Yin (2016) defines an online classroom community in four dimensions. They include spirit, trust, interaction and finally commonality of expectation and goals.

Seppala and Alamaki, (2003) as cited in Kim, Lee and Kim, (2014) corroborated this when they stated that students could also enjoy the increased frequency of social interaction through mobile technology in group-based projects. Rovai (2002) as cited in Yin (2016) enumerated factors that may hinder interaction in the online classroom community to include: knowledge and personalities, communication styles, reluctance to criticize, fear of criticism and confusion of feedback.

\section{Collaborative learning and 'WhatsApp'}

Due to the group-based feature of WhatsApp, it is necessary to examine the application's effort in fostering collaborative learning. Dillenbourg (1999) explained collaborative learning as when two or more people come to learn something together. Collaborative learning concerns learners in active group participation throughout the entire learning process (Monteiro and Morrison, n.d). According to Kim, Lee and Kim (2014), collaborative learning can be achieved via different tools, such as discussion boards, blogs, and instant messenger. Social media's potential strength to facilitate collaborative learning appears evident, and it is supported by scholarly literature (Junco et al, 2011; Brown, 2012; Novak et al, 2012). According to Cornell University cited in Johansson (2016: 4) "when students learn together with others, for instance in discussion settings that provide group solving tasks or content, they are part of a collaborative learning environment". Collaborative learning could motivate participants, and also arouse their interest (Njoku and Prince, 2015; Yin, 2016; Monteiro and Morrison, n.d). Also, Eccles and Tenenbaum (2004) as cited in Kim, Lee and Kim (2014), opine that collaborative learning needs team-related skills and task-related skills to enable team members to work together smoothly and efficaciously. Soomro, Kale and Zai (2014) as cited in Johansson (2016) mentioned in their article, for social media or any other ICT device to attain its full potential in collaborative learning is much dependent on everyone stays active and wants to contribute to the learning process.

According to Yin (2016), students use WhatsApp to create class publications by publishing their work in the group. WhatsApp enhances online collaboration and communication and promotes students' performance (Barhoumi, 2015). This study will further explore the mobility of learning. In as much learn- 
ing in the ICT age is collaborative; it is pertinent to stress that it is also mobile.

\section{Defining and conceptualizing mobile learning}

Alexander (2004) explains that mobile learning, also known as m-learning is a type of learning that is mediated through a mobile device. He further asserts that m-learning establishes the legality of pastoral learners. Mobile learning is the adoption of wireless and digital technologies used by learners as they engage in higher education learning (Traxler, 2007). Motiwalla (2007) in a related study submits that the awareness and support for mobile learning within the student population is enormous. Similarly, Amry (2014) demonstrates the usefulness of WhatsApp in this regard. The two terminologies under scrutiny in this concept are mobility and learning. El-Hussein and Cronje (2010) state thus: Mobility refers to the ability of the technology within the physical contexts and activities and the students as they participate in the higher learning's institution. In other words, it refers to the exercise of the learning process, the behaviors of the learners as they adopt the technology in learning. It also refers to the attitude of students who are themselves highly mobile as they use mobile technology for learning process.

On the other hand, learning is the acquisition of ideas or knowledge in an environment. In this regard, learning is confined to mobile devices. This is how the phenomenon of mobile learning or m-learning came evolved. Traxler (2007) succinctly opines that m-learning is not limited to mobility or 'learning; it is a fraction of a new mobile conception of society. M-learning opens the mind to the possibility of a new model and encourages us to abandon the restraints of our habitual ways of thinking, learning, communicating, designing and reacting (El-Hussein and Cronje 2010).

Furthermore, El-Hussein and Cronje divided the concept of m-learning into three critical areas: the mobility of technology, the mobility of learner, and the mobility of learning. They further wrote that the learner and the learning process take place in an uninterrupted continuum within the social context of education. The three ingredients are not independent and are equally essential in enhancing mobile devices necessary instruments for the delivery of instructional contents in higher institutions (El-Hussein and Cronge, 2010).

Figure 1. The three components of mobile learning

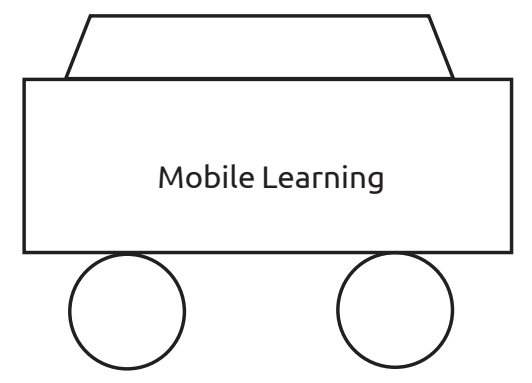

Mobility of Technology

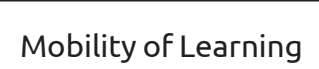

Mobility of Learner

32 | ETKileşim | Yıl 3|Sayı 5| Nisan 2020 
- The mobility of technology: El-Hussein and Cronje (2010) referred to the mobility of technology as advanced cell phones and other forms of technology like smartphones, digital cameras, iPods and Personal Digital Assistant (PDAs).

- The mobility of learning: Walter (2007) stressed that mobility of learning is unique because the learning happens within the environment a learner is situated at a particular time. He argues that the context is personalized. It is different compared to the traditional lecture room.

- The mobility of learner: Mobile learning is learner-centric because it is mobile and nomadic compared to the traditional method of learning that is teacher-centric. The learner can learn while on the move.

\section{Theoretical Frameworks}

'Technology Acceptance Model' (TAM) stands out in investigating issues affecting users' acceptance of modern technology. 'Technological Acceptance Model' or popularly called TAM is technology theory of new age that explains how users come to acquire and utilize new technology. Fred Davis proposed TAM in 1989. The scholar exemplified that the attitude of a user toward a system was a dominant determinant of whether the user will use or reject the system. Davis writes that (as cited in Chuttur, 2009) the approach of the user, in turn, was considered to be determined by two major assumptions: "perceived usefulness and perceived ease of use, with perceived ease of use having a direct influence on perceived usefulness". 'Perceived usefulness' (PU) is a strong factor that determines user acceptance, adoption, and usage of technology (Mathieson, 1991). It is defined as "the degree to which a person believes that using a particular technology system would enhance his or her academic performance" (Davis et al, 1989). The more positive one's attitude toward technology usage, the better he/she performs in education.

'Perceived ease-of-use' (PEOU) is another key factor in TAM. It refers to "the degree to which a person believes that using technology will be easy and free from effort" (Davis et al, 1989). Zhu, Linb and Hsu (2012) submit that perceived ease of use signifies the degree to which an individual accepts that using technology would be effortless, and hassle-free. According to Davis (1989), 'perceived ease-of-use' may guarantee the early acceptance of innovation, and it is necessary for technological adoption. In the opinion of Bagozzi (as cited in Durodolu, 2016) argues that TAM anticipated that attitudes would have a positive influence on the mindset that would gear human efforts towards the use of technology.

The application of the TAM has helped to confirm that age, education, earnings, and race are associated with beliefs of the importance of information and conviction can influence attitudes towards and use of skills that will 
enhance access to information (Durodolu, 2016). Technology Acceptance Model (TAM) underpins this study as it explored undergraduates WhatsApp experiences, and their attitudes towards the adoption of WhatsApp in learning.

\section{Methodology}

This study adopted both quantitative and qualitative research methods. In other words, the study adopts the mixed-method, also known as dual-method. The researcher chose both methods because of the fact that one method strengthens the weakness of the other and further help to lay more credence to the findings of the other method. For the quantitative method, the study adopted the survey design while Focus Group Discussion (FGD) was used for the qualitative method. The population of the study for this study is the undergraduate students of the University of Abuja, Gwagwalada, Nigeria. The method for determining sample size for the study- survey quantitative methodology is Taro Yamane (1967) statistical method for determining sample size for a given population:

$$
n=\frac{N}{1+N(e)^{2}}
$$

Where:

$$
\begin{aligned}
& \mathrm{n}=\text { Sample size } \\
& \mathrm{N}=\text { Population under study } \\
& \mathrm{e}=\text { Margin of error or level of precision (0.05) }
\end{aligned}
$$

The population of University of Abuja undergraduates is 20,693 . The sample size will be calculated thus:

$$
\frac{n=20,693,000}{1+20,693(0.005)^{2}}
$$

From this calculation, a sample size of 400 was adopted, but the quantitative analysis was based on the 393 duly returned questionnaire. The study adopted Simple Percentage Table (SPT) and Microsoft Office tools to analyse the quantitative data. For the FGD, the discussion was transcribed into full text using express scribe transcriptions software and the contents were thematically analysed.

In a study such as this, it is critical that all participants gave their informed consents prior to inclusion in the study, which was what the researcher did for before adopting the participants for the study. Besides, the study was ap-

34 ETKileşim |Yıl3|Sayı $5 \mid$ Nisan 2020 
proved by the University of Abuja ethics committee and has been performed in accordance with the laid down ethical standards.

\section{Analysis and Findings}

\section{Analysis of quantitative findings}

Finding from social SNS preference indicate that 172 respondents, i.e. $45 \%$ aver that WhatsApp is their most preferred social networking site. Next to their preference is Facebook; 136 respondents representing 37\% indicated that Facebook is their preferred SNS. Twitter has $14 \%$ of the respondents aver that they prefer it, while $11 \%$ and $2 \%$ indicate that Instagram and Snapchat are their preferred SNS respectively. From the chart, it is obvious that WhatsApp is the preferred SNS among the respondents.

Furthermore, 135 respondents representing 36.2\% have been on WhatsApp between 4 to 6 years. The least number of year(s) the respondents have been on WhatsApp is less than a year: 21 respondents, i.e., $5.6 \%$. On the number of hours spent on WhatsApp in a day, 127 respondents representing $34.1 \%$ spend above 5 hours on WhatsApp on a daily basis. Still, on table 3, the frequency at which respondents check their WhatsApp messages is also presented here. 113 , i.e., $30.3 \%$ respondents aver that they check their WhatsApp messages several times in a day, that is, more than ten times a day.

Respondents' reasons for using WhatsApp revealed that 52 respondents representing $13.9 \%$ use WhatsApp because it is free of charge and easy to use. 41 of the respondents, that is, $11.0 \%$ claim they use the SNS because it enables multimedia messaging. $5.3 \%$ of the respondents aver that they use the platform because their friends and family use it. $13.1 \%$ of the respondents say they use due to its ability to facilitate group discussion. And finally, 210 respondents', i.e., $56.4 \%$ claim that their reasons for using WhatsApp are all the enumerated options.

Figure 2. Indicating students' responses on WhatsApp group potential to engender collaborative learning.

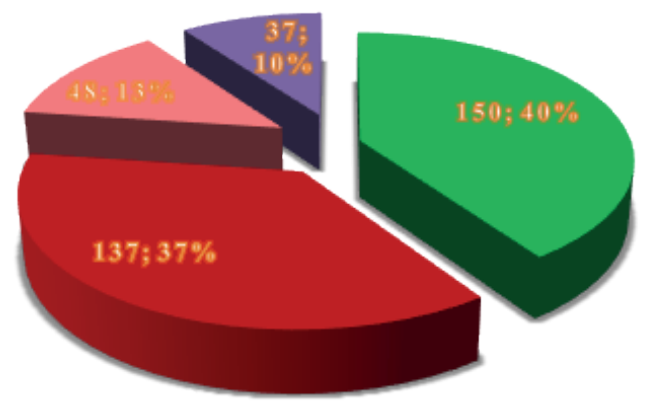

Strongly Agree

- Agree

- Disagree

n Strongly Disagree 
From above chart, 150 of the respondents, that is, $40 \%$ strongly agree that WhatsApp group encourages the collaborative exchange of academic ideas. $37 \%$ agree, $13 \%$ disagree and $10 \%$ strongly disagree. The data reveal that the majority of the respondents (40\%) surveyed strongly agreed that their class WhatsApp group encourages collaborative learning.

Figure 3. Opinion of respondents on WhatsApp platform as an academic learning platform.

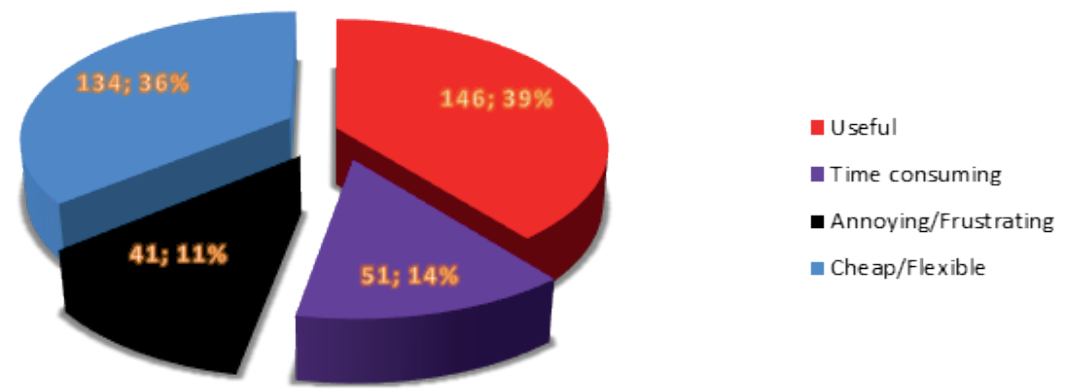

Table 1. Indicating challenges students encounter while using WhatsApp.

\begin{tabular}{|l|l|c|c|}
\hline Question & Responses & Frequency & Percentage \\
\hline \multirow{2}{*}{$\begin{array}{l}\text { Challenges } \\
\text { students } \\
\text { encounter } \\
\text { while using } \\
\text { WhatsApp }\end{array}$} & $\begin{array}{l}\text { Posting unrelated and irrelevant } \\
\text { contents }\end{array}$ & 296 & $79.5 \%$ \\
\cline { 2 - 4 } & Bad network & 44 & $11.8 \%$ \\
\cline { 2 - 4 } & Low battery & 21 & $5.6 \%$ \\
\cline { 2 - 4 } & All the options & 11 & $2.9 \%$ \\
\hline & & $\mathbf{3 9 3}$ & $\mathbf{1 0 0 \%}$ \\
\hline
\end{tabular}

The Table 1. above indicates that $79.5 \%$ of the respondents, that is, 296 of the respondents aver that the major challenge they encounter is the irrelevant post. This shows that most respondents do not like when irrelevant comments are posted on the platform. This statistics further reveals that "unrelated and irrelevant topics" is a major challenge undergraduate encounter while using WhatsApp.

Figure 4. Respondents on class WhatsApp platform.

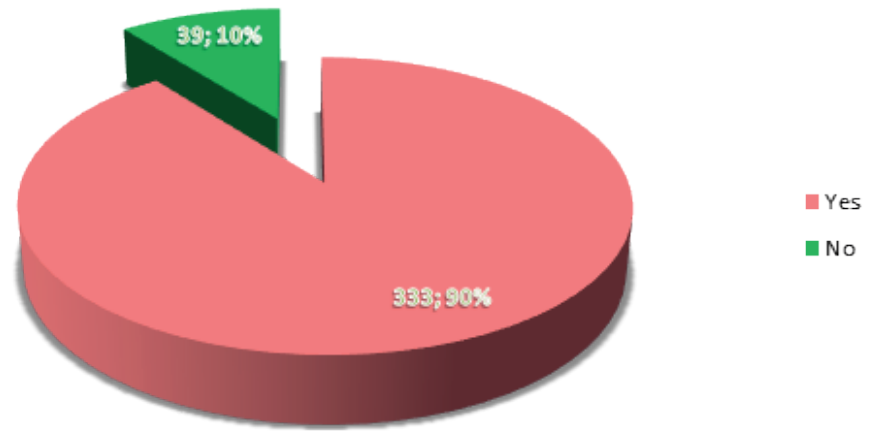

36 | ETKileşim | Yıl 3 |Sayı $5 \mid$ Nisan 2020 


\section{Thematic analysis of qualitative data}

Qualitative data analysis revealed some overarching themes across the discussion. The themes are organized in tandem with the research objectives:

\section{- 'WhatsApp' is popular}

During the enlistment of participants for the focus group, a screener was distributed to potential discussants in order to investigate if they are in their various classes WhatsApp groups. On retrieving the twenty consent forms, it revealed that all the potential discussants are on the class WhatsApp group. This shows the popularity of WhatsApp among undergraduates. It is no longer news that young people are tech-savvy; they dictate the tune of technology.

\section{- Cheap and easy to use}

Discussion from the focus group revealed an overarching theme of "cheap, and "easy". The students aver that WhatsApp is cheap and easy to use. From their explanation of WhatsApp, it is clear that their main reason for using WhatsApp is due to its affordability and ease of use. Excerpts from a participant in the discussion read: "WhatsApp is a like a medium through which a group of people with similar ideas, pursuing similar purpose converge in an easiest possible way". Another member of the group clearly articulates their thought thus: "...easier way because it will not be easy for the course rep to be calling everybody individually. When it is posted on the WhatsApp group everybody will have access to it and it is cheaper". The preference of WhatsApp by the discussants to other social networking sites is an indication that WhatsApp is a popular social media platform among undergraduates

\section{- Economy of use compared to the conventional phone call and SMS}

It is glaring that WhatsApp is used more for communication among undergraduates. This is probably due to the affordability and ease of use of the mobile application. A discussant even averred that his course rep does not pick phone call sometimes, "Like my course rep when you call him, sometimes he will not pick. But when you send him WhatsApp message he replies immediately". Another member of the group believes in WhatsApp's voice call. "The WhatsApp voice call is cheaper than the normal call. Sometimes I prefer to load hundred naira credit and convert it to $100 \mathrm{MB}$ and use it for WhatsApp solely". There was some uniformity among members of the group when a discussant disclosed that using conventional phone call or SMS is like wasting his money.

\section{- Lectures notifications}

One dominant theme in the discussion is lecture notification. Most participants claim that WhatsApp affords them the avenue to receive lectures notifications. They also averred that WhatsApp reduces the workload of the course representative. A participant narrates his experience: "Class WhatsApp group is a medium through the course members get information about their lecture 
updates and venue where the lecture is taking place". It is obvious from the assertions above that the course rep cannot call everyone to inform them of classes.

\section{- Irrelevant posts}

From the body of the data, it was discovered that the major challenge undergraduates encounter in class WhatsApp group are irrelevant comments and posts. Most participants obviously claimed that students are fond of posting unrelated and irrelevant comments on the platform. "The major challenge I have is the irrelevant information being passed. You see irrelevant pictures being posted..." Another participant said, "Irrelevant messages being posted will not allow you to get the relevant information".

\section{- Class-related information}

Overall, participants claimed that they exchanged class related information on the WhatsApp group. According to the participants, the class-related information includes information relating to lecture notifications and happening around the department. However, it was pointed out that aside from class-related information, the platform is used for other activities:

Aside from class-related information, there is vital information going around within the school that are vital to the students. Such information is passed through the class WhatsApp. And other information that can help citizens of the country is passed through the WhatsApp group.

\section{- Collaborative exchange of academic ideas}

The argument that emerged on this theme was balanced. Half of the participants claimed that they have engaged in a form of collaborative learning on their class WhatsApp group, while the other half claimed otherwise. According to a participant, Douglas (not real name), who apparently has engaged in collaborative learning in his WhatsApp group, gave an insight into the nature of the collaboration. "In our own WhatsApp group, I can remember vividly, last session, a lecturer was really giving us assignments upon assignments. During that period, when some people ask of the question..."

However, as noted earlier, there were arguments by some participants that collaborative exchanges of academic ideas are rare in their class WhatsApp group. One of the arguments emanated from Ryan, (not real name) a final year student. According to him: "I think, based on that, based on my experience in class WhatsApp group, most students see it as a place for chatting..." As regards academic stuff it is a rare thing. It is rare. "I think it is very crucial for students to see WhatsApp as more of academic stuff than chatting".

As stated earlier on, the crux of this study is to investigate to what extent class WhatsApp group could engender collaborative learning among undergraduates. From the analysis above, it can be deduced that findings from the qualitative study stand at $50 \%$. This means that, to an extent, WhatsApp

38 | ETKíleşim | Yıl 3 |Sayı 5 | Nisan 2020 
could engender collaborative learning among undergraduates. However, findings from the survey clearly indicated that out of the 372 respondents, 150 respondents, that is, $40 \%$ of the respondents surveyed strongly agree that WhatsApp encourages collaborative learning and 137 respondents, that is, $37 \%$ agree that the platform engenders collaborative learning.

\section{Discussion}

After a thorough analyses of qualitative and quantitative data resulting from the survey and focus group discussion, findings reveal that WhatsApp is the most used and preferred social networking sites among undergraduates. This revelation corroborates previous studies in the literature. Cankaya and Yunkul (2018) found in their study that WhatsApp is the most used social networking sites by participants in a mixed method study. Similarly, Abdulla (2017) also discovered that among other social networking sites like Twitter, Instagram, and Facebook, WhatsApp is the most preferred by university students. Besides, Ling (2016) and Yin (2016), both studies carried out in Malaysia found that WhatsApp is the preferred social networking site among Malaysian student. The popularity of WhatsApp could be ascribed to the application's affordability and ease of use. Users of WhatsApp do not need to login to use the application. The messaging platform is always open. In addition to this, the medium is rich in multimedia messaging. It is easier to send text, pictures, document, locations, and voice notes and so on.

Furthermore, it was discovered from both the qualitative and quantitative analyses data that WhatsApp is affordable and easy to use. A study by Gasaymeh (2018) made a similar discovery. According to Gasaymeh, the integration of WhatsApp into education is fun, easy and simple. This finding is in tandem with revelation from this study. There are plethora of studies that corroborate this result (Church and Oliviera, 2013; Yeboah and Ewur 2014; Alsaleem, 2014; Ling, 2016; Yin, 2016; Mefolere, 2016; Mistar and Embi, 2016; Ellanti et al, 2017; Raiman et al, 2017). These studies discovered that WhatsApp is affordable and easy to use. According to Ellanti et al, (2017: 1), "compared to conventional pager, the use of WhatsApp is easy, inexpensive, and reliable and can help improve the efficiency of communication within a surgical team". It is glaring from these studies that the affordability and ease of use of WhatsApp is a major factor that endears people to the medium. It is important to reiterate that comments from the focus group as participants attested that using their phone to make calls when they have WhatsApp mobile application is a waste of money.

As stated earlier, the crux of this study is to ascertain if the class WhatsApp group could engender collaborative learning. Surprisingly, the study found that to a large extent some form of collaboration in learning could take place on WhatsApp. This result agrees with numerous studies. Sarwar et al, (2018) assert that social networking sites serve as an important platform that facil- 
itates the development of learning environments by engendering collaboration and articulation among students. Similarly, Kurundawade and Kavale (2018: 198) argue thus: "collaborative learning activities have helped in evolving as a better learner through collaboration". Rajiv et al, (2017) affirm that $78 \%$ of the respondents, the learning capabilities of WhatsApp group while $89 \%$ of the participants advocated that WhatsApp group should be adopted as an adjunct to classroom teaching regarding ubiquitous availability and collaborative learning. Bouhnik and Deshen (2014) in an Israeli University showed that teachers who initiated WhatsApp groups with their high school students achieved four goals: communicating with students, grooming a positive atmosphere and a sense of belonging in the class, creating a dialogue and using and sharing a learning platform. It is pertinent to state that with this revelation, it is important to domesticate WhatsApp into a formal learning environment. A plethora of these studies were carried out in higher institutions, and most of the participants are young people. It has been established that young persons are tech-savvy; they are trend-setters in the use and adoption of new technology for various purposes.

This study also commits to the literature on mobile learning also known as m-learning. WhatsApp is a mobile application; it is portable and flexible. Findings from the study indicate that participants can communicate and learn through WhatsAPP wherever they may be. According to Boyinbode et al., (2017), confirm that due to the media richness of WhatsApp, it is more suitable for mobile learning. The following statistics from their study show social media applications that will best engender mobile learning are as follows: $65 \%$ for WhatsApp, 25\% for Email, 10\% for Twitter, and 10\% for BBM. Similarly, a study by Rajiv et al (2017) further corroborates this finding. According to the scholars, $74 \%$ of the study participants affirmed the capability of WhatsApp m-learning. "WhatsApp learning is asynchronous learning that still provide a low-stress environment and within a more flexible time frame" (Rajiv et al, 2017: 3663). El-Hussein and Cronje (2010) cite that m-learning creates a sense of ownership of content, enhances collaborative activities all of which are essential features of a mobile learning device.

Despite the numerous merits of WhatsApp as discovered in this study, there were some downsides to the use of the mobile application. Chief among them is the posting of irrelevant contents on WhatsApp groups. Participants from both the survey and focus group discussion attested that the major challenge they encounter is the posting of unrelated and irrelevant contents. In line with this finding, a number of studies have equally discovered a similar trend. Hamad (2017) found that there was no discipline in the group; participant post irrelevant contents. Similarly, Rajiv et al (2017) conclude that challenges experienced by users of WhatsApp include deviation and distraction, non-availability of web service, the low dedication of some student, time-consuming. 
Theoretically, findings from this study have contributed to the body of knowledge on the two theories that undergird this study- Technology Acceptance Model and the Domestication Theory. Firstly, findings from the study succinctly revealed that perceived usefulness and perceived ease of use as postulated in the theory, Technology Acceptance Model (TAM) have a paramount role to play in participant use of WhatsApp. Major discoveries from the study indicate that the population of study рrefer and use WhatsApp due to its affordability and ease of use. Zhu, Linb and Hsu (2012) postulated that perceived ease of use signifies the degree to which an individual accepts that using certain technology would be effortless and hassle-free. This assertion corroborates findings from this study as captured above. Davis, Bagozzi and Warshaw, (1989) gave an insight into the explanation of perceived usefulness. The scholar wrote it is the degree to which a person believes that using a particular technology system would enhance his or her academic performance. The ability of WhatsApp to hold a group of up to two hundred and fifty-six is enough for the study population to domesticate the mobile application for whatever purpose they deem fit; in this case, it is for collaborative learning. Obviously, WhatsApp group corroborates this angle of TAM theory- perceived usefulness. Overall, these discoveries have made a meaningful contribution to the body of literature on Technology Acceptance Model theory.

Summarily, findings from the study reveal that to a large extent WhatsApp engenders collaborative learning among undergraduates. This is due to its affordability and ease of use. Similarly, result from the study also revealed that WhatsApp is the most preferred social networking site among undergraduate. The ability of the mobile application to facilitate group communication is yet another feature that endears students to WhatsApp. The study also discovered that participants often use WhatsApp for communication compared to conventional phone calls and SMS. Overall, students prefer WhatsApp because of its affordability and ease of use. However, there were some challenges participants experienced while using WhatsApp. A major challenge as discovered from both the survey and focus group is the challenge of irrelevant posts. Participants complained that some members of the group post comments that are unrelated and irrelevant to the class group. As stated earlier on, the study concludes that to a large extent WhatsApp engenders collaborative learning among undergraduates.

\section{Conclusion and Recommendations}

Harnessing the potentials of new media is a habit that individuals should cultivate. Over time there has been the argument that social media is bad. But the power to make any medium good or bad resides in the use to which its users put it to. There are enormous powers in social media. Vallor (2010) reiterated that individuals need to learn to cultivate certain "virtue" that will enable them to realise the potential of socially and personally satisfying forms of commu- 
nicative interaction online. Apparently, from my review of literature, the African society is lagging behind in realising the potentials of the social media, particularly WhatsApp. Majority of the literature reviewed in the study emanated from the Middle East and Asia. Scholars and students in these regions are finding ways to formally domesticate WhatsApp for learning in schools. In Nigeria particularly, there is an apparent lack of this virtue as postulated by the scholar above. There is the need for Africa to wake up and do the needful. Media technologies should be explored in view of their inherent potentials and how such potentials could be harnessed appropriately. The adoption of technology in education is becoming necessary, and technology is the chief driver of most part of a country's economy and education is not an exception.

Based on findings from this study, the following recommendations are put forth:

i. There should be the allocation of fund to the study of technologies and its impact on learning. A careful look at the literature of the study will reveal that the African continent is lagging behind in this knowledge domain. The Middle East and the Asians, particularly Malaysians are the trend-setter in WhatsApp studies. The interests of young scholars need to be directed to this path.

ii. There is a need for lecturers to see WhatsApp as a learning platform. Unfortunately, findings from this research revealed that most class WhatsApp groups are created by students. There is a need to have an instructor in the student WhatsApp group. With this, the posting of irrelevant comment will be minimised. Besides, lecturers could initiate WhatsApp group where they would serve as the administrator; they could post lectures notifications, assignment, quiz and they could hold a discussion on the platform. As an administrator, the lecturer would have the power to unregister any student that does not abide by the rules the platform.

iii. This study also recommends that training on the use of social media for learning should be conducted for scholars. Lecturers should be trained on the potentials of social media in easing their jobs. It may not be wrong to argue that most Nigerian lecturers do not have a good knowledge of social media.

iv. Students should see the positive impacts of using social media, particularly, using WhatsApp to engender learning. They should desist from having the thinking that social media are for mere pleasantries. They possess the power to fine-tune the use of WhatsApp to something worthwhile. Class WhatsApp groups administrators should set rules that prohibit posting of irrelevant contents on the group, and defaulters should be severely punished; it may be to unregister defaulters from the group.

v. There is a need for higher institutions of learning to provide amenities like constant electricity and good mobile network. It is such facilities that engender the working of mobile phones. Without such amenities, the use of so-

42 | ETKíleşim | Yıl3|Sayı 5 Nisan 2020 
cial media for learning may be frustrating.

vi. Social media could be addictive; it is recommended that students and lecturers should exercise some caution in the use of social media. They should know when to access their messages; not when face to face lectures are going on. This could be distracting.

\section{References}

Abdulla, J. M. D. (2017). "The Impact of Using Social Media and Internet on Academic Performance: Case Study Bahrain Universities". EAl Endorsed Transactions on Scalable Information Systems. 4(13). 1-12. doi: 10.4108/eai.28-62017.152748.

Ahad, A. D. and Lim, S. (2014). "Convenience or Nuisance? The "WhatsApp" Dilemma". The International Conference on Communication and Media. http:// www.repo.uum.edu.my.

Alenazi, A. A. (2018). "WhatsApp Messenger as a Learning Tool: An Investigation of Pre-service Teachers' Learning without Instructor Presence". Journal of Education and Training Studies. 6(1). 1-8. doi:10.11114/jets.v6i1.2684.

Alexander, B. (2004). "Going Nomadic: Mobile Learning in Higher Education”. Educause Review. 39(5). 28-35.

Alghamdi, E. A., Rajab, H., Rashid, S. S. (2016). “Unmonitored Students Self-created WhatsApp Groups in Distance Learning Environments: A Collaborative Learning Tool or Cheating Technique". International Journal of Research Studies in Educational Technology. 5(2). 71-82.

Alsaleem, B. I. A. (2014). "The Effect of Whatsapp Electronic Dialogue Journaling on Improving Writing Vocabulary Word Choice and Voice of EFL Undergraduate Saudi Students". Arab World English Journal. 4(3). 213-225. www. awej.org/index.php?option=com_content\&view=article\&id330:basma-issa-ahmad-alsaleem\&catid=42\&ltemid 133 .

Amry, A. B. (2014). "The Impact of Whatsapp Mobile Social Learning on the Achievement and Attitudes of Female Students Compared with Face-ToFace Learning in the Classroom". European Scientific Journal. 1(22). 116136. www.eujournal.org/index.php/esj.

Andújar-Vaca, A., Cruz-Martínez, Maria, S. (2017). "Mobile Instant Messaging: Whatsapp and Its Potential to Develop Oral Skills". Media Education Research Journal. 25(50). 43-52. https://doi.org/10.3916/C50-2017-04.

Ansary, M. S. and Behera, S. K. (2018). "A Review of Related Literature on Mobile Learning". International Journal of Engineering Trends and Applications (IJETA). 5(1). 1-13. ISSN: 2393-9516.

Arthur-Nyarko, E. (2017). "Effect of the Use of Instant Messaging Applications on Writing of English as a Second Language in Higher Education". European Journal of Education Studies. 3(11). 861-880. Doi:10.5281/zenodo.1148814. 
Asika, N. (2006). Research Methodology in the Behavioural Science. Lagos: Longman Publishers.

Ayotunde, A. (2012). "Changing Technology and the Nigerian Mass Media”. Kuwait Chapter of Arabian Journal of Business and Management Review. 2(3). 94101.

Bansal, T. and Joshi, D. (2014). "A Study of Students Experiences of Mobile Learning". Global Journal of Human Social Science Research. 14(4). 27-33. http:// socialscienceresearch.org/index.php/GJHSS/article/view/126.

Barhoumi, C. (2015). "The Effectiveness of WhatsApp Mobile Learning Activities Guided by Activity Theory on Students' Knowledge Management". Contemporary Educational Technology. http://www.cedtech.net/search.asp.

Bouhnik, D. and Deshen, M. (2014). "WhatsApp Goes to School: Mobile Instant Messaging between Teachers and Students". Journal of Information Technology Education: Research. 13. 217-231. http://www.jite.org/documents/ Vol13/JITEv13ResearchP217-231Bouhnik0601.pdf.

Boyd, D. M. and Ellison, N. B. (2007). "Social Network Sites: Definition, History and Scholarship". Journal of Computer-Mediated Communication. 13(1). 210-230. onlinelibrary.wiley.com/doi/10.1111/j.1083-6101.2007.00393.x/abstract.

Boyinbode, O. K., Agbonifo, O. C., Ogundare, A. (2017). "Supporting Mobile Learning with WhatsApp Based on Media Richness". Circulation in Computer Science. 2(3). 37-46. https://doi.org/10.22632/ccs-2017-251-89.

Brown, S. (2012). "Seeing Web 2.0 in Context: A Study of Academic Perceptions". The Internet and Higher Education. 15(1). 50-57.

Cankaya, S. and Yunkul, E. (2018). "Learner Views about Cooperative Learning in Social Learning Networks". International Education Studies. 11(1). 52-63.

Chu H. H. and Toh, L. L. (2014). "Interactive Character Learning Model (Iclm)-Chinese Character Learning Using Whatsapp for Malay L3 Learners". US-China Education Review A. 4(11). 777-786. http://www.davidpublishing.com.

Church, K. and de Oliveira, R. (2013). "What's up with Whatsapp? Comparing Mobile Messaging Behaviour with Traditional Sms". Proceedings of the 15th International Conference on Human-computer Interaction with Mobile Devices and Services. Munich, Germany. 352-361.

Chuttur, M. Y. (2009). "Overview of the Technology Acceptance Model: Origins, Developments and Future Directions". Working Papers on Information Systems. 9(37). 9-37. https://www.academia.edu/11030173/TAMReview.

Creswell, J. W. (2014). Research Design: Qualitative, Quantitative and Mixed-Methods Approaches. https://www.researchgate.net/file.PostFileLoader.html.

Davis, F. D, Bagozzi, R. P., Warshaw, P. R. (1989). “User Acceptance of Computer Technology: A Comparison of Two Theoretical Models". Journal of Management Science. 35(8). 982-1003.

44 | ETKileşim | Yıl 3|Sayı 5| Nisan 2020 
Dillenbourg, P. (1999). "Introduction: What Do You Mean by Collaborative Learning?". P. Dillenbourg (ed.) Collaborative Learning: Cognitive and Computational Approaches. (1-19). Oxford, UK: Elsevier Science.

Downes, S. (September 10, 2008). Connectivism and Its Critics: What Connectivism is Not. www.downes.ca/post/53657.

Duke, B., Harper, G., Johnston, M. (2013). “Connectivism as A Digital Age Learning Theory". The International HETL Review-Special Issue. https://www.hetl. org.

Durodolu, O. O. (2016). "Technology Acceptance Model as a Predictor of Using Information System to Acquire Information Literacy". Library Philosophy and Practice. 1450. digitalcommons.unl.edu/cgi/viewcontent.cgi?article $=4029$ \&context=libphilprac.

El-Hussein, M. O. M. and Cronje, J. C. (2010). "Defining Mobile Learning in the Higher Education Landscape". Educational Technology \& Society. 13(3). 12-21.

Ellanti P., Moriarty A., Coughlan F. (2017). "The Use of WhatsApp Smartphone Messaging Improves Communication Efficiency Within an Orthopaedic Surgery Team". Cureus. 9(2). doi: 10.7759/cureus.1040.

Ellison, N. B. and Boyd, D. M. (2013). "Sociality through Social Network Sites". W.H. Dutton (ed.) The Oxford Handbook of Internet Studies. (151-172). Oxford: Oxford University Press.

Enriquez, T. J, Kuiatese, A., Mullen, M., Newton, A., Whelchel, E. (2014). Domestication Theory. https://prezi.com/gzrkyjnm7qg9/domestication-theory/.

Faud, N., Madar, A. R., Marwan, M. E. (2013). "An Overview of Mobile Application for Student of Kolej Poly-Tech Mara (Kptm) By Using Mobile Phone". www. aessweb.com/pdf-files/jasr-3(6)-527-537.pdf.

Gachago, D., Strydom, S., Hanekom, P., Simons, S., Walters, S. (2015). “Crossing Boundaries: Lecturer's Perspective on the Use of Whatsapp to Support Teaching and Learning in Higher Education". Progressio. 37(1). 172-187. https://www.researchgate.net/.../290339914_Crossing_boundaries_lecturers'_perspective.

Gasaymeh, A. M. (2017). “University Students' Use of Whatsapp and Their Perceptions Regarding Its Possible Integration into Their Education". Global Journals Inc. (USA). 17(1).

Gimranova, S., Nurmanova, M., Cohenmiller, A. S. (2018). "Texting to Motivate Language Learning: Whatsapp Group Chats and Near Peer Role Modeling (NPRM)". LEARNing Landscapes. 11(1). 121-135. http://www.learninglandscapes.ca/index.php/learnland/article/view/927.

Glasow, P. A. (2005). Fundamentals of Survey Research Methodology. https:// www.mitre.org/sites/default/files/pdf/05_0638.pdf.

Hamad, M. M. (2017). “Using WhatsApp to Enhance Students' Learning of English Language Experience to Share". Canadian Center of Science and Education. 7(4). doi:10.5539/hes.v7n4p74. 
Helen, B. (2002). An Introduction to Online Communities. www.providersedge.com/ docs/km.../an_introduction_to_online_communities.pdf.

Huang, Y.-M., Huang, T.-C., Hsieh, M.-Y. (2008). “Using Annotation Services In A Ubiquitous Jigsaw Cooperative Learning". Educational Technology \& Society. 11(2). 3-15.

Hyne, D. and Richardson, H. (2009). "What Use Is Domestication Theory to Information Systems Research?". Handbook of Research on Contemporary Theoretical Models in Information Systems. (482-494). IGI Global. http://biblio. uabcs.mx/html/libros/pdf/11/27.pdf.

Hynes, D. (2007). "Applying Domestication: How The Internet Found Its Place in The Home". Information Resource Management Association Proceedings. Vancouver BC, Canada.

Jisha, K. and Jebakumar. (2014). "Whatsapp: A Trend Setter in Mobile Communication Among Chennai Youth". IOSR Journal of Humanities and Social Science. 19(9). 01-06. www.iosrjournals.org.

Johansson, V. (2005). "Social Media in Collaborative Learning-Literature Review". https://www.researchgate.net/.../295672849_Social_media_in_Collaborative_learning_-...

Junco, R., Heiberger, G., Loken, E. (2011). "The Effect of Twitter On College Student Engagement and Grades". Journal of Computer Assisted Learning. 27(2). 119-132.

Kaplan, A. M. and Haenlein, M. (2010). "Users of The World, Unite! The Challenges and Opportunities of Social Media". Business Horizons. 53(1). 59-68.

Khalaf, K. M. B. (2017). "The Effect of E-Mail and Whatsapp on Jordanianefl Students' Reading Skill". Arab World English Journal. 8(2). 228-237. doi: https:// dx.doi.org/10.24093/awej/vol8no2.16.

Kim, H., Lee, M., Kim, M. (2014). "Effects of Mobile Instant Messaging on Collaborative Learning Processes and Outcomes: The Case of South Korea". Educational Technology \& Society. 17(2). 31-42.

Kopung, J. K. (2016). Exploring The Use of Whatsapp Instant Messaging as A Platform for Pre-Service Teachers' Learning of Mathematics: A Mixed Methods Approach. (Unpublished Master Thesis). South Africa: University of KwaZulu-Natal. researchspace.ukzn.ac.za/bitstream/handle/.../Kopung_Kabelo_Joseph_2016.pdf?...

Kothari, C. R. (2004). Research Methodology: Methods and Techniques. New Delhi: New Age International Publishers.

Kudzayi, S. T. and Ronald, M. (2017). "Social Media Tools in Education: A Case of WhatsApp Use by Heritage Studies Teachers in Zimbabwe". Greener Journal of Social Sciences. 7(4). 34-40. doi: http://doi.org/10.15580/ GJSS.2017.4.082217108.

Kurundawade, S. M. and Kavale, S. M. (2018). "IIEECP Intervention in Teaching-Learning Process: An Experience". Journal of Engineering Education Transformations. 31(3). 192-199.

46 | ETKíleşim | Yıl 3|Sayı 5| Nisan 2020 
Ling, H. Y. (2016). Investigating the Perception of Secondary School Students in Kuching, Sarawak in Using WhatsApp for Communication and Learning Purposes. (Unpublished Master Thesis). Malaysia: Wawasan Open University. woulibrary.wou.edu.my/theses-project/MED2016_YLHSU.pdf.

Longman Active Study Dictionary $5^{\text {th }}$ Edition. (2010). Harlow, United Kingdom: Pearson Education Limited.

Maria, J. (2016). "Use of Whatsapp to Enhance Reading and Writing Skills at Undergraduate College Level". Language in India. 16(11).47-60.

Mefolere, K. F. (2016). "WhatsApp and Information Sharing: Prospect and Challenges". International Journal of Social Science and Humanities Research. 4(1). 615-625.

Minalla, A. A. (2018). "The Effect of WhatsApp Chat Group in Enhancing EFL Learners' Verbal Interaction Outside Classroom Contexts". English Language Teaching. 11(3). 1-7. doi: 10.5539/elt.v11n3p1.

Minhas, S., Ahmed, M., Ullah, Q. (2016). "Usage of Whatsapp: A Study of University of Peshawar, Pakistan". International Journal of Humanities and Social Science Invention. 5(7). 71-73.

Minocha, S. (2009). "A Case Study Based Investigation of Students' Experiences with Social Software Tools". New Review of Hypermedia and Multimedia. 15. 245-265.

Mistar, I. B. and Embi, M. A. (2016). "Students' Perception On the Use of Whatsapp as A Learning Tool in ESL Classroom". Journal of Education and Social Sciences. 4. 96-104. jesoc.com/wp-content/uploads/2016/08/Edu-76.pdfch.

Module 4 - Theories to Help You: Technology Determinism. (n.d). http://ocw.library.nenu.edu.cn/pluginfile.php/17592/mod_resource/content/1/module04.pdf.

Monteiro, M. S. and Morrison, K. (n.d). Collaborative, Online and Blended Learning in Undergraduate Teaching and Learning; Symbiosis or Marriage of Convenience.chtl.hkbu.edu.hk/documents/elfa2013/Session2E-S3-forweb.pdf.

Motiwalla, L. (2007). "Mobile Learning: A Framework and Evaluation". Journal of Computer and Education. 49. 581-596.

National Youth Policy. (2001). http://www.un.org/esa/socdev/unyin/documents/ tc_nigeria_nyp_2001.pdf.

Njoku, U. and Prince, C. (2015). "Information and Communication Technologies to Raise Quality of Teaching and Learning in Higher Education Institutions". International Journal of Education \& Development using Information \& Communication Technology. 11(1). 122-147. http://web.a.ebscohost.com.ezproxy.ub.gu.se/ehost/pdfviewer/pdfviewer?sid=4ba9d8a-cc99-468a-a50c-fb9125d3d731\%40sessionmgr4002\&vid=15\&hid=4109.

Novak, E., Razzouk, R., Johnson, T. (2012). "The Educational Use of Social Annotation Tools in Higher Education: A Literature Review". The Internet and Higher Education. 15(1). 39-49. 
Nyiri, K. (2002). "Towards A Philosophy of M-Learning". Proceedings of the IEEE International Workshop on Wireless and Mobile Technologies in Education. Vaxjo, Sweden.

Plana, M. G. C., Escofet, M. I. G, Figueras I. T., Gimeno, A., Appel, C., Hopkins, J. (2013). “Improving Learners' Reading Skills Through Instant Short Messages: A Sample Study Using WhatsApp". Worldcall 2013-CALL: Sustainability and Computer-Assisted Language Learning. Conference Proceedings. (8084). Northern Ireland: University of Ulster. http://www.researchgate.net/ publication/255718202.

Pollizi, G. (2011). "Measuring School Principals' Support for Ict Integration In Palermo, Italy". Journal of Media Literacy Education. 3(2). 113-122. http://www. jmle.org. 6 March 2012.

Raiman, L., Antbring, S., Mahmood, S. (2017). “Whatsapp Messenger as a Tool to Supplement Medical Education for Medical Students on Clinical Attachment". BMC Medical Education. 17(7). doi:10.1186/s12909-017-0855-x.

Rajiv, R., Amit, J., Anil, S.B. (2017). “Whatsapp-Assisted Learning of Anatomy as an Adjuvant to Traditional Class-Room Learning: Achievements and Prospect". International Journal of Anatomy and Research. 5(1). 3659-3664. doi: https://dx.doi.org/10.16965/ijar.2017.133.

Rambe, P. and Chipunza, C. (2013). “Using Mobile Devices to Leverage Student Access to Collaboratively-Generated Resources. A Case of Whatsapp Instant Messaging at A South-African University". International Conference on Advanced Information and Technology for Education. (331-335). https://www. researchgate.net/publication/2666452_Using_mobile_devices_to_leveragestudent_access_to_collaborativelygenerated_resources_a_case_of_ Whatsapp_instant messaging_at_a_South_African_University.

Riyanto, A. (2013). English Language Learning Using Whatsapp Application. http:// akhmadriyantoblog.wordpress.com/2013/02/21/english-language-learning-using-whatsapp-application/.

Rovai, A. P. (2002). "Building Sense of Community at a Distance". International Review of Research in Open and Distance Learning. 3(1). www.irrodl.org/index. php/irrodl/article/view/79/153.

Sajithra, K. and Patil, R. (2013). "Social Media-History and Components". IOSR Journal of Business and Management. 7(1). 69-74. www.iosrjournals.org/iosrjbm/papers/Vol7-issue1/10716974.pdf?id=5311.

Sarwar, B., Zulfiqar, S., Aziz, S., Chandia, K. E. (2018). “Usage of Social Media Tools for Collaborative Learning: The Effect on Learning Success with the Moderating Role of Cyberbullying". Journal of Educational Computing Research. 1-34. doi: 10.1177/0735633117748415.

Sawyer, R. (2011). "The Impact of New Social Media on Intercultural Adaptation". Senior Honors Projects. 242. http://www.digitalcommons.uri.edu/srhonorsprog/242.

Silverstone, R., Hirsch, E., Morley, D. (1992). "Information and Communication

48 | ETKileşim | Yıl 3|Sayı $5 \mid$ Nisan 2020 
Technologies and The Moral Economy of the Household". R. Silverstone and E. Hirsch (eds.) Consuming Technologies Media and Information in Domestic Spaces. London and New York: Routledge.

Social Research Update 19: Focus Groups. (1997). http://sru.soc.surrey.ac.uk/ SRU19.html.

Statista. (2017). Most Popular Mobile Messaging Apps Worldwide as of January 2017, Based On Number of Monthly Active Users (In Millions). https:// www.statista.com/statistics/258749/most-popular-global-mobile-messenger-apps/.

"Technology Determinism". (n.d). Wikipedia. https://is.muni.cz/el/1421/podzim 2016/VIKBB55/um/07_technological_determinism.pdf.

"Technology Determinism by Marshall McLuhan". (n.d). http://www.doctordi.ca/ COMS201/TechDeterminism.html.

Teo, T. (2013). "A Comparison of Non-Nested Models in Explaining Teachers' Intention to Use Technology". British Journal of Educational Technology. 44(3). 81-84. doi:10.1111/j.1467-8535.2012.01350.x

Ting, Y. R. (2005). "Mobile Learning: Current Trend and Future Challenges". Proceedings of the Fifth International Conference on Advanced Learning Technologies. Los Alamitos, CA: IEEE Computer Society Press.

Traxler, J. (2007). "Defining, Discussing and Evaluating Mobile Learning: The Moving Finger Writes and Having Writ...". The International Review in Open and Distance Learning. 8. 1-13.

Trinder, J. (2005). "Mobile Technologies and Systems". A. and Kuklska-Hulme (eds.) Mobile Learning: A Handbook for Educators and Trainers. USA: Taylor \& Francis.

Unicef. (n.d). Online Communities: Connecting Online to Improve a Shared Practice and to Spark Innovation. https://www.unicef.org/knowledge-exchange/.../ Online_Communities_production.pdf.

United Nations. (n.d). "Definition of Youth". http://www.un.org/esa/socdev/documents/youth/fact-sheets/youth-definition.pdf.

Vallor, S. (2010). "Social Networking Technology and the Virtues". Ethics and Information Technology. 12(2). 157-170.

Walker, K. (2007). "Introduction: Mapping the Landscape of Mobile Learning". M. Sharples (ed.) Big Issue in Mobile Learning: A Report of a New Workshop by the Kaleidoscope Network of Excellence Mobile Learning Initiative. (5-6). University of Nottingham, UK: Learning Science and Research Institution.

WhatsApp. (n.d). Whatsapp FAQ-Using Whatsapp Group Chat. https://www. whatsapp.com/faq/en/general/21073373.

Willemse, J. (2015). "Undergraduate Nurses Reflections on Whatsapp Use in Improving Primary Health Care Education". Curationis. 8(2). http://dx.doi. org/10.4102/curationis.v38i2.1512.

Wimmer, R. D. and Dominick, J. R. (2011). Mass Media Research: An Introduction. 
Boston, MA: Cengage Learning.

Yamane, T. (1967). Statistics: An Introductory Analysis. New York: Harper and Row.

Yeboah, J. and Ewur, G. D. (2014). "The Impact of Whatsapp Messenger Usage on Students Performance in Tertiary Institutions in Ghana". Journal of Education and Practice. 5(6). 157-164. www.iiste.org/journals/index.php/JEP/ article/view/11241.

Yin, L. C. (2016). Adoption of Whatsapp Instant Messaging Among Students in Ipoh Higher Education Institution. (Unpublished Master Thesis). Malaysia: Wawasan Open University. woulibrary.wou.edu.my/theses-project/MED2016_ CYLEE.pdf.

Zhu, D., Linb, C. T., Hsu, Y. (2012). “Using the Technology Acceptance Model to Evaluate User Attitude and Intention of Use for Online Games". Total Quality Management. 23(8). 965-980. 
